\title{
PERANCANGAN MODEL SISTEM INTELIJENSIA BISNIS UNTUK MENGANALISIS PEMASARAN PRODUK ROTI DI PABRIK ROTI MENGGUNAKAN METODE DATA MINING DAN CUBE
}

\section{MODEL BUSINESS INTELLIGENCE SYSTEM DESIGN TO ANALYZE MARKETING BREAD PRODUCT IN BREAD FACTORY USING DATA MINING AND CUBE METHOD}

\author{
Rina Fitriana*), Johnson Saragih, dan Besty Afrah Hasyati \\ Laboratorium Sistem dan Simulasi Industri, Jurusan Teknik Industri, Fakultas Teknologi Industri, Universitas Trisakti \\ Kampus A, Jl. Kyai Tapa No.1, Grogol, Jakarta Barat 11440 \\ E-mail :rinaf@trisakti.ac.id
}

Makalah: Diterima 4 Januari 2018; Diperbaiki 18 April 2018; Disetujui 25 April 2018

\begin{abstract}
Business intelligence systems participate to deliveran accurate and useful information to decision makers in marketing division of bakeries manufacture. The purpose of this study was to design business intelligence model to analyze the marketing product, design the data mining model, measure and analyze the marketing process of the product they sell. The methodology of this research wasto analyze system requirements, design unified modeling language, make process extract, transform, and load, designdata warehouse, and data mining that integrated with the on line analytical process cube webbased. The business intelligence model produced was a marketing data mining model and on line analytical process cube. The result from on line analytical process cube was the data warehouse of transaction in $R$ Bakery. In designing the data mining, $K$ means clustering method was used. The results from data mining k-means clustering were there were $83 \%$ cluster 1 and 17\% cluster 2. Cluster 1 wasthecategorize for low leftover breads and cluster 2 was the categorize for high leftover breads. The model cube recency, frequency, and monetary and customer lifetime value resulted ranked out of the most amount of sales in $R$ Bakery.
\end{abstract}

Keywords: business intelligence system, data mining, extract transform load, on line analitical process cube

\section{ABSTRAK}

Sistem intelijensia bisnis dapat berperan serta sebagai alat untuk memberikan informasi yang akurat dan berguna bagi pengambil keputusan bagian pemasaran dalam pabrik roti. Tujuan pada penelitian ini adalah merancang model sistem intelijensia bisnis untuk menganalisa pemasaran produk di pabrik roti, merancang model data mining, mengukur dan menganalisa proses pemasaran produk. Metodologi penelitian pada penelitian ini adalah menganalisis kebutuhan sistem, mendesain unified modeling language, melakukan proses extract, transform, load, merancang data warehouse, data mining yang berintegrasi menggunakan metode on line analytical process cube yang berbasis web. Model sistem intelijensia bisnis yang dihasilkan berupa model pemasaran data mining dan on line analitical process cube. Hasil yang diperoleh dari on line analitical process cube adalah berupa data warehouse penjualan $\mathrm{R}$ Bakery. Dalam mendesain data mining yaitu menggunakan metode clustering K-means. Hasil data mining clustering k-means adalah terdiri atas $83 \%$ cluster 1 dan $17 \%$ cluster 2. Cluster 1 merupakan kategori sisa roti yang rendah dan cluster 2 merupakan kategori sisa roti yang tinggi. Model cube recency, frequency, monetary dan customer lifetime valuemenghasilkan ranking penjualan terbanyak dari pedagang di R Bakery.

Kata kunci : sistem intelijensia bisnis, data mining, extract transform load, on line analytical process cube

\section{PENDAHULUAN}

Sistem intelijensia bisnis dapat berperan serta sebagai alat untuk memberikan informasi yang akurat dan berguna bagi pengambil keputusan bagian pemasaran dalam pabrik roti. Pada pabrik roti $\mathrm{R}$ Bakery sistem intelijensia bisnis diperlukan sehingga dapat membantu memecahkan permasalan pada pemasaran roti.

Tujuan yang ingin dicapai dalam penelitian ini adalah merancang model sistem intelijensia bisnis dan data mining untuk menganalisis pemasaran produk di pabrik roti $\mathrm{R}$ Bakery, mengukur dan menganalisis proses pemasaran produk berdasarkan metode OLAP $(\mathrm{On}$ Line Analytical Process) Cube dan data mining, menentukan ranking pedagang berdasarkan hasil penjualan menggunakan metode CLV (Customer Lifetime Value).

Intelijensia bisnis adalah suatu cara untuk mengumpulkan, menyimpan, mengorganisasikan, membentuk ulang, meringkas data serta menyediakan informasi, baik berupa data aktifitas bisnis internal perusahaan, maupun data aktivitas bisnis eksternak perusahaan termasuk aktifitas bisnis para pesaing yang mudah diakses serta dianalisis 
untuk berbagai kegiatan manajemen (Edward, 2000). Extract Transform Load (ETL) mengacu pada perangkat lunak yang ditujukan untuk tampil di sebuah otomatisasi dengan cara tiga fungsi utama : ekstraksi, transformasi dan loading data ke data warehouse (Vercelis, 2009). Spoon merupakan integrated development environment (IDE) yang berupa graphical user interface (GUI) yang digunakan untuk merancang, menyunting dan menjalankan job dan transformation. Online transactional processing (OLTP) adalah teknologi untuk mengelola aplikasi yang berorientasi pada transaksi. OLAP adalah teknologi untuk menjawab kebutuhan analitik. Setiap tahapan memiliki kemampuan untuk memberikan penjelasan mengenai baris yang dikeluarkannya. Penjelasan dari baris ini disebut dengan row metadata. Row metadata mengandung informasi seperti nama, tipe data, lebar data, lebar presisi desimal. (Mulyana, 2014).

Data Mining adalah suatu proses menemukan hubungan yang berarti, pola, dan kecendrungan dengan memeriksa dalam sekumpulan besar data yang tersimpan dalam penyimpanan dengan menggunakan teknik pengenalan pola seperti statistik dan matematika (Larose, 2006). K-means clustering merupakan salah satu metode data clustering non-hirarki yang mengelompokan data dalam bentuk satu atau lebih cluster/kelompok. Data-data yang memiliki karakteristik yang sama dikelompokan dalam satu cluster/kelompok dan data yang memiliki karakteristik yang berbeda dikelompokan dengan cluster/kelompok yang lain sehingga data yang berada dalam satu cluster/ kelompok memiliki tingkat variasi yang kecil (Agusta, 2007).

Struktur operasional utama dalam OLAP didasarkan pada konsep yang disebut kubus (cube) (Turban et al., 2011). Kubus (cube) didalam OLAP adalah struktur data multidimensional (actual atau virtual) yang memungkinkan analisis data yang cepat. Juga dapat didefinisikan sebagai kemampuan dari memanipulasi dan menganalisis data secara efisien dari berbagai perspektif.

Customer life time value (CLV) menggambarkan nilai sekarang dari arus laba masa depan (net present value of the stream of future profit) yang diharapkan selama pembelian seumur hidup pelanggan (Kotler, 2009). Perusahaan harus mengurangi dari pendapatan yang diharapkan biaya untuk menarik, menjual dan melayani pelanggan itu. Menghitung CLV mempunyai banyak aplikasi dan beberapa pengarang telah mengembangkan modelmodel untuk aplikasinya seperti alokasi sumber daya pemasaran (Ming et al., 2008), harga (Hidalgo, 2007) dan segmentasi konsumen (Haenlien et al., 2007); (Benoit et al., 2009).

Beberapa penelitian mengenai sistem intelijensia bisnis telah dilakukan oleh para peneliti diantaranya Penelitian di bidang sistem intelijensia bisnis telah banyak dilakukan oleh para peneliti diantaranya penelitian penerapan sistem manajemen mutu dalam ISO-9001 : 2000-berbasis standar layanan intelijensia bisnis. (Cartaya, 2008). Stefanovic (2009) melakukan penelitian intelijensia bisnis rantai pasok dan arsitektur rantai pasok intelijensia bisnis. Data mining memungkinkan pengguna untuk menyaring melalui sejumlah besar informasi yang tersedia di gudang data dan dari proses pengacakan intelijensia bisnis dapat ditemukan (Pillai, 2011). Jie (2010) meneliti data mining yang efisien dan mempresentasikam kerangka sistem intelijensia bisnis berdasarkan paradigm computational intelligence, yang meliputi alat prediksi berdasarkan neurocomputing. Kantor komisi pendidikan tinggi menggunakan Microsoft SQL Server 2005 untuk integrasi data intelijensia bisnis enterprise untuk mengembangkan system pendukung keputusan (Ko, 2007). Liu (2010) melakukan penelitian mengenai analisis penerapan intelijensia bisnis dalam integrasi rantai pasokan. Dengan kubus OLAP, dapat secara interaktif mengiris kubus data di beberapa dimensi dan menelusuri untuk lebih detail (Maira, 2009). Ming (2010) meneliti pendekatan dari hybrid fuzzy-DelphiAHP untuk mendukung system intelijensia bisnis untuk membuat keputusan bisnis yang lebih baik. Ada tiga pendekatan intelijensia bisnis dari yaitu pendekatan manajerial, teknis dan sistem. (Ghazanfari, 2011). Pendekatan manajerial diharapkan dengan adanya intelijensia bisnis dapat menghasilkan proses pengambilan keputusan yang efektif dan efisien bagi manajemen. Pendekatan teknis membahas peralatan dan software yang mendukung proses intelijensia bisnis. Pendekatan sistem membahas nilai tambah untuk mendukung sistem informasi. Beberapa sistem intelijensia bisnis telah berhasil, salah satu faktornya mereka mengunakan software yang telah disediakan oleh Microsoft, Oracle, SAP dan lain-lain. Topik yang terintegrasi dengan sistem intelijensia bisnis adalah manajemen rantai pasok, customer relationship management, data mining, data warehouse, sistem pendukung keputusan, performance scorecard, manajemen pengetahuan, business process management, artificial intelligence, enterprise resource planning, extract transformation loading, OLAP, sistem manajemen kualitas dan manajemen strategi (Fitriana et al., 2011). Peran sistem intelijensia bisnis adalah membuat dan mengembangkan database menjadi data warehouse dan mengintegrasikan sub model mutu dengan metode fuzzy dan sub model CRM dengan metode OLAP cube untuk dapat menganalisis dan mendukung pengambilan keputusan secara intelijen, membuat optimisasi dan mengembangkan model, mengembangkan alat-alat pendukung keputusan, meningkatkan kepuasan pelanggan dan stakeholder (Fitriana et al., 2012). Suatu kerangka kerja untuk merancang metode proses querying, yaitu teknik pengelolaan (otomatis) dari repositori proses yang 
dirancang dan dijalankan, serta model yang menggambarkan hubungan antara proses. (Polyvyanyy, 2017). Tabel penelitian mengenai sistem intelijensia bisnis di seluruh dunia dan posisi penelitian disajikan pada Tabel 2.

Adapun posisi penelitian ini di antara penelitian-penelitian lainnya, dapat dilihat dari aspek metodologi penelitian yang merupakan gabungan antara antara UML, ETL, OLAP, Cube dan Data Mining Clustering. Untuk aspek komoditas, dipilih komoditas roti. Ruang lingkup penelitian di pabrik roti dengan studi kasus pada R Bakery. Untuk aspek software menggunakan software Pentaho.

\section{METODE PENELITIAN}

Metode penelitian merupakan langkahlangkah yang dilakukan dalam penelitian yang digambarkan secara terstruktur untuk memudahkan peneliti dalam melakuan penelitian. Metodologi penelitian yang dilakukan dalam penelitian dapat dilihat pada Gambar 1.

\section{HASIL DAN PEMBAHASAN}

Input pada sistem ini adalah data penjualan roti dan data produksi. Pada Gambar 2 menjelaskan input hingga output pada pembuatan sistem intelijensia bisnis pada penelitian di R Bakery. Data penjualan meliputi data penjualan per cabang dan jenis roti yang dijual selama 6 bulan. Untuk cabang binong mulai dari bulan Juni 2016 hingga bulan November 2016, sedangkan untuk cabang Perumnas mulai dari bulan April 2016 hingga September 2016. Pada sistem intelijensia ini terdapat atribut dan performansi untuk peningkatan pemasaran. Faktor yang merupakan pengaruh dari sistem intelijensia bisnis antara lain stakeholder yang merupakan pegawai pabrik dan pedagang roti, kemudian terdiri visi, misi dan tujuan dari perusahaan $\mathrm{R}$ Bakery. Sistem intelijensia bisnis ini akan menghasilkan output berupa model sistem intelijensia bisnis cube dan data mining yang mana dari hasil output tersebut akan menampilkan hasil visual yang akan membantu dalam pengambilan keputusan.

Untuk mengetahui permasalahan dan menganalisa kebutuhan sistem dapat dilakukan menggunakan metode PIECES yaitu melakukan analisis terhadap kinerja, informasi, ekonomi, keamanan, aplikasi, efisiensi, dan pelayanan pelanggan dengan tujuan mengoreksi atau memperbaiki sistem yang sudah ada (Whitten, 2004).

Tabel 2. Penelitian terkait dan posisi penelitian (Fitriana, 2013 diedit)

\begin{tabular}{|c|c|c|}
\hline No & Topik & Nama Pengarang \\
\hline 1 & Integrasi antara intelijensia bisnis, supply chain & (Liu, 2010); (Stefanovic, 2009) \\
\hline 2 & Integrasi antara intelijensia bisnis, data mining & (Pillai, 2011) \\
\hline 3 & integrasi antara intelijensia bisnis, AI (artificial intelligence) & (Hayashi ,2010), (Ming Kuen, 2010) \\
\hline 4 & Integrasi antara intelijensia bisnis dan olap & (Gofarelli, 2012) \\
\hline 5 & Integrasi antara intelijensia bisnis, quality management system & (Cartaya, 2008) \\
\hline 6 & Integrasi antara intelijensia bisnis,CRM, data mining & (Phan, 2010) \\
\hline 7 & $\begin{array}{l}\text { Integrasi antara intelijensia bisnis, DSS, performance } \\
\text { scorecard }\end{array}$ & (Ko, 2007); (Kleesuwan et al., 2010) \\
\hline 8 & Integrasi antara intelijensia bisnis, AI dan, data mining & (Kamel, 2002); (Head,2010) \\
\hline 9 & $\begin{array}{l}\text { Integrasi intelijensia bisnis, data mining, knowledge } \\
\text { management }(\mathrm{KM})\end{array}$ & (Houxin, 2010) \\
\hline 10 & $\begin{array}{l}\text { Integrasi antara intelijensia bisnis, business process } \\
\text { management (BPM), KM }\end{array}$ & (Marjanovic, 2010) \\
\hline 11 & Integrasi antara intelijensia bisnis,CRM, SCM dan ERP & (Ghazanfari, 2011) \\
\hline 12 & Integrasi antara intelijensia bisnis, ETL dan OLAP & (Fuentes, 2010); (Maira, 2009) \\
\hline 13 & $\begin{array}{l}\text { Integrasi antara intelijensia bisnis, data mining, DSS, } \\
\text { manajemen strategi }\end{array}$ & $(\mathrm{Li}, 2008)$ \\
\hline 14 & Integrasi antara intelijensia bisnis, CRM dan AI & $(\mathrm{Jie}, 2010)$ \\
\hline 15 & $\begin{array}{l}\text { Integrasi antara intelijensia bisnis, UML, datawarehouse, } \\
\text { Fuzzy, ETL, OLAP, cube, decision tree, data mining. }\end{array}$ & (Fitriana, 2013) \\
\hline 16 & Integrasi antara intelijensia bisnis, service quality, data mining & (Fitriana,2016) \\
\hline 17 & $\begin{array}{l}\text { Integrasi antara sistem intelijensia bisnis, kualitas, Data } \\
\text { Mining, OLAP Cube, K-Means Clustering }\end{array}$ & (Fitriana, 2017) \\
\hline 18 & $\begin{array}{l}\text { Integrasi antara intelijensia bisnis, UML, datawarehouse, ETL, } \\
\text { OLAP, cube, clustering, data mining }\end{array}$ & Posisi Penelitian ini \\
\hline
\end{tabular}




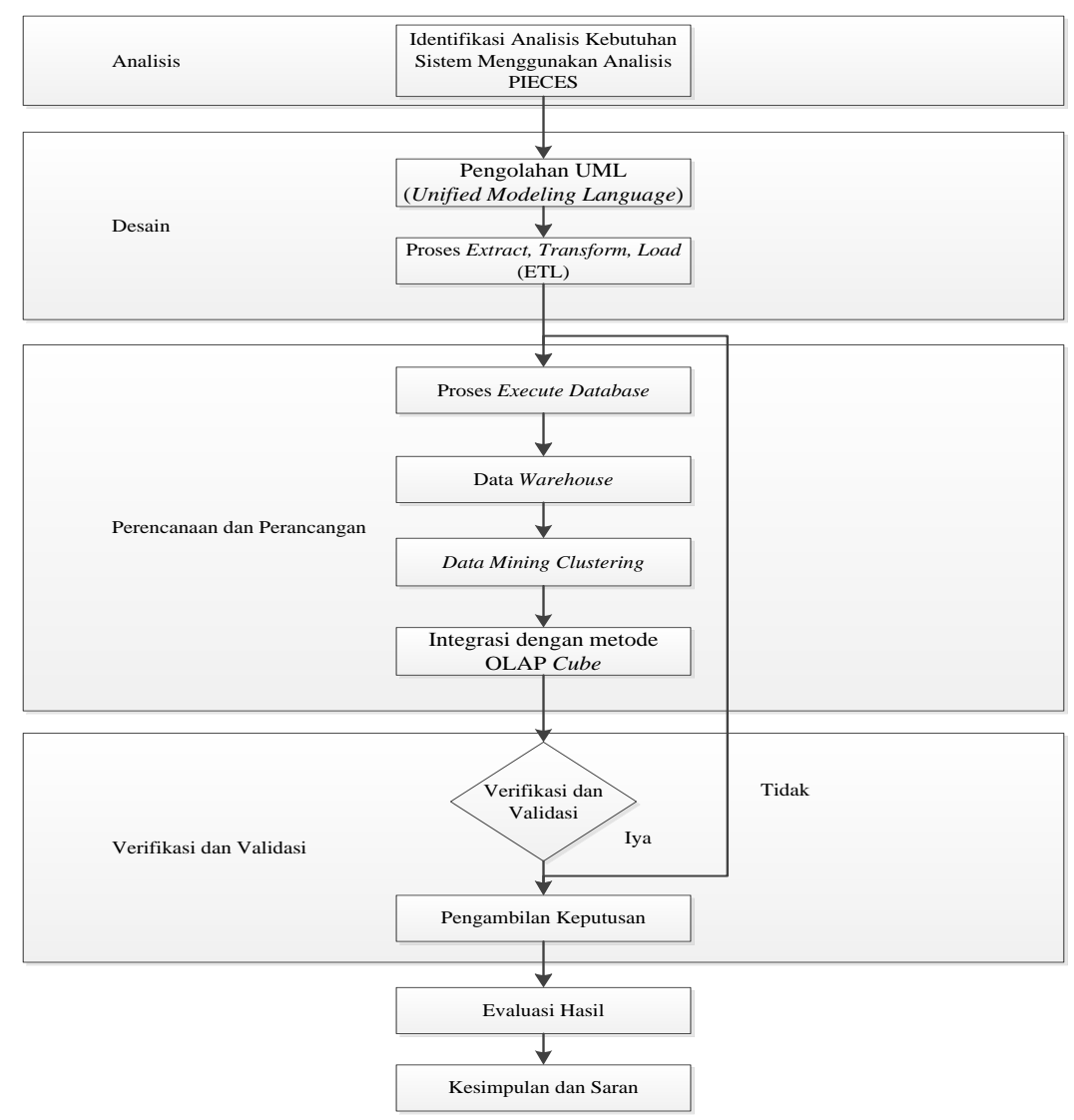

Gambar 1. Flow chart metodologi penelitian

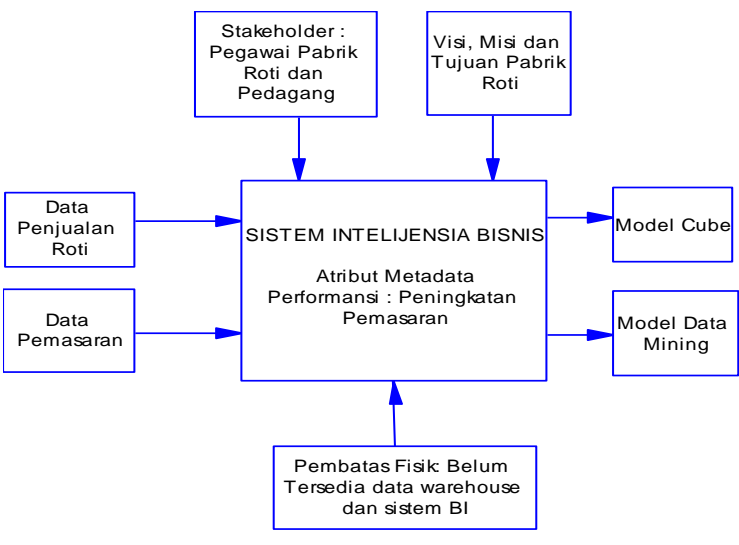

Gambar 2. Sistem intelijensia bisnis

Hal-hal yang dianalisa yaitu performansi (performance), informasi (information), ekonomi (economic), keamanan (control/security), efisiensi (efficiency), dan layanan (service). Pada Tabel 2 adalah analisa PIECES perusahaan R Bakery.

\section{Desain UML (Unified Modelling Language)}

Sequence diagram adalah suatu diagram yang menggambarkan sejumlah objek yang berguna untuk merangkai pesan yang dikirim antara objek yang juga berinteraksi antara objek. (Whitten, 2004).
Gambar 3 merupakan sequence diagram untuk metode OLAP cube dapat dilihat aktor yang yang berperan dalam perancangan sistem tersebut yaitu kepala produksi yang berperan sebagai pembuat sistem, MySQL, spoon dan pentaho yang merupakan sistem tersebut. MySQL adalah software untuk menyimpan database setelah proses ETL dengan menggunakan software spoon. Kemudian setelah database tersimpan kemudian menampilkan hasil dan grafik OLAP cube pada software Pentaho.

\section{Membuat Datawarehouse dan Model Sistem Intelijensia Bisnis}

Untuk membuat rancangan sistem intelijensia bisnis, yang harus dilakukan adalah mendesain datawarehouse yang akan dibuat. Namun diperlukannya model arsitektur sistem intelijensia untuk gambaran dari sistem. Gambar 4 menyajikan arsitektur sistem intelijensia yang akan dibuat.

\section{Data Warehouse}

Data Warehouse merupakan pusat data yang dibentuk dari hasil penggabungan dan pengolahan data dari berbagai sumber data (Mulyana, 2014). Software yang digunakan untuk data warehouse di penelitian ini adalah SQLYog 
Tabel 1. Analisis PIECES

\begin{tabular}{|c|c|c|}
\hline PIECES & Sistem Lama & Sistem Baru \\
\hline Performance & $\begin{array}{l}\text { Membutuhkan waktu yang lama untuk } \\
\text { mengetahui jumlah penjualan dari dua } \\
\text { cabang dikarenkan pencatatan data masih } \\
\text { manua; }\end{array}$ & $\begin{array}{l}\text { Pengolahan data berupa jumlah } \\
\text { penjualan per cabang yang dapat } \\
\text { diakses secara terkomputerisasi }\end{array}$ \\
\hline Information & $\begin{array}{l}\text { Data yang tersedia kurang akurat } \\
\text { dikarenakan sering terjadinya kesalahan } \\
\text { dalam penghitungan jumlah penjualan dari } \\
\text { pedagang }\end{array}$ & $\begin{array}{l}\text { Informasi lebih akurat dan minimnya } \\
\text { terjadi kesalahan pada pengolahan } \\
\text { data }\end{array}$ \\
\hline Economic & $\begin{array}{l}\text { Pencatatan hasil penjualan dilakukan secara } \\
\text { manual }\end{array}$ & $\begin{array}{l}\text { Membutuhkan biaya untuk membeli } \\
\text { laptop attau komputer dan } \\
\text { memberikan pelatian sofware kepada } \\
\text { karyawan }\end{array}$ \\
\hline Control/Security & $\begin{array}{l}\text { Keamanan sangat minim dikarenakan data } \\
\text { yang dihasilkan berupa arsip dan buku } \\
\text { sehingga beresiko untuk terjadinya } \\
\text { kekeliruan dalam penulisan }\end{array}$ & $\begin{array}{l}\text { Lebih aman dan memberikan hasil dan } \\
\text { keputusan yang lebih cepat }\end{array}$ \\
\hline Efficiency & Membutuhkan lebih banyak waktu & Hemat waktu, efisien dan efektif \\
\hline Service & $\begin{array}{l}\text { Pencarian data rumit dan lama dikarenakan } \\
\text { data masih berantakan dan tidak rapi }\end{array}$ & $\begin{array}{l}\text { Memperoleh hasil dan keputusan yang } \\
\text { lebih cepat dikarenakan lebih mudah } \\
\text { dalam mengakses data dengan } \\
\text { menggunakan sistem intelijensia } \\
\text { bisnis }\end{array}$ \\
\hline
\end{tabular}

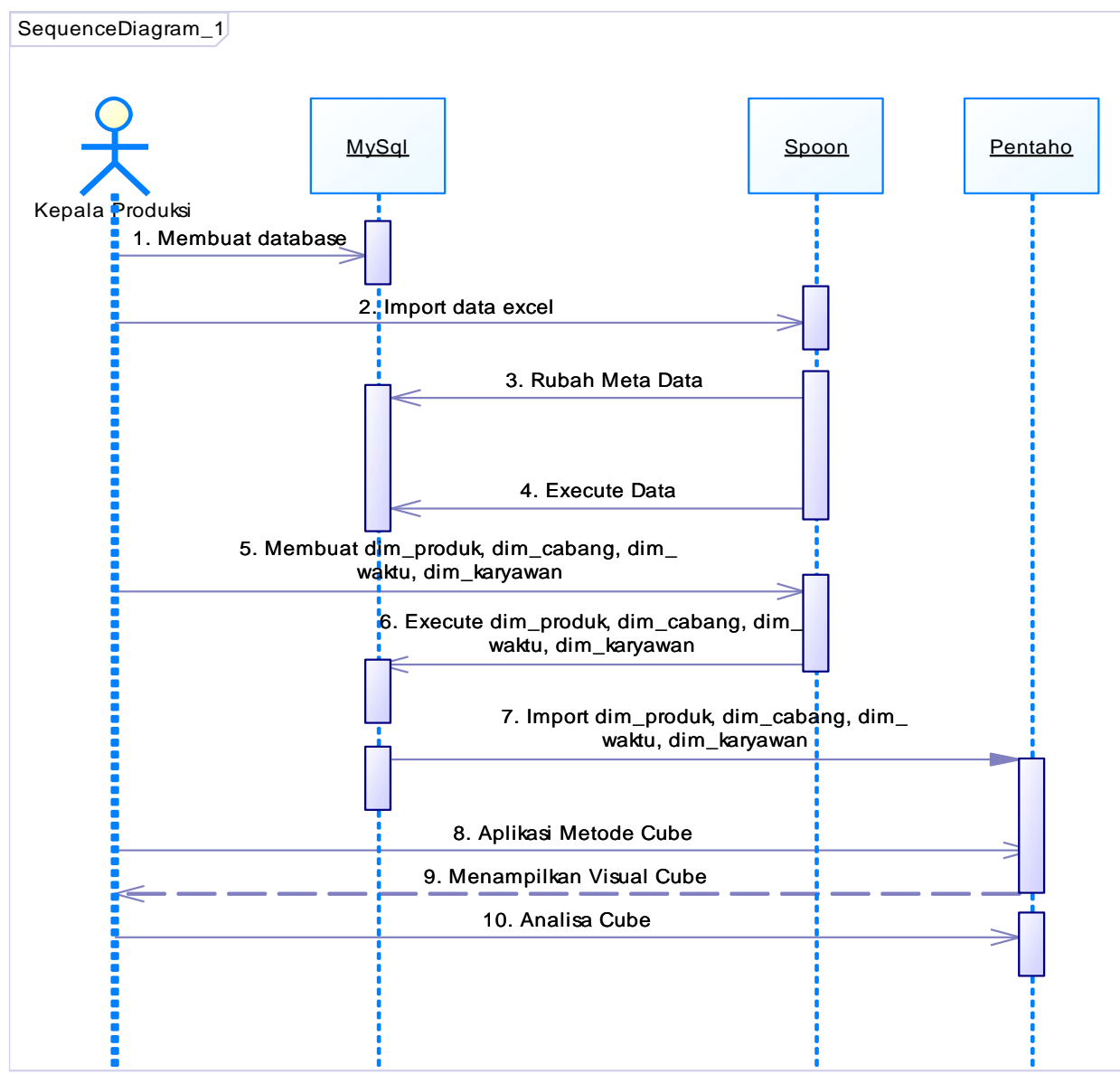

Gambar 3. Sequence diagram cube 


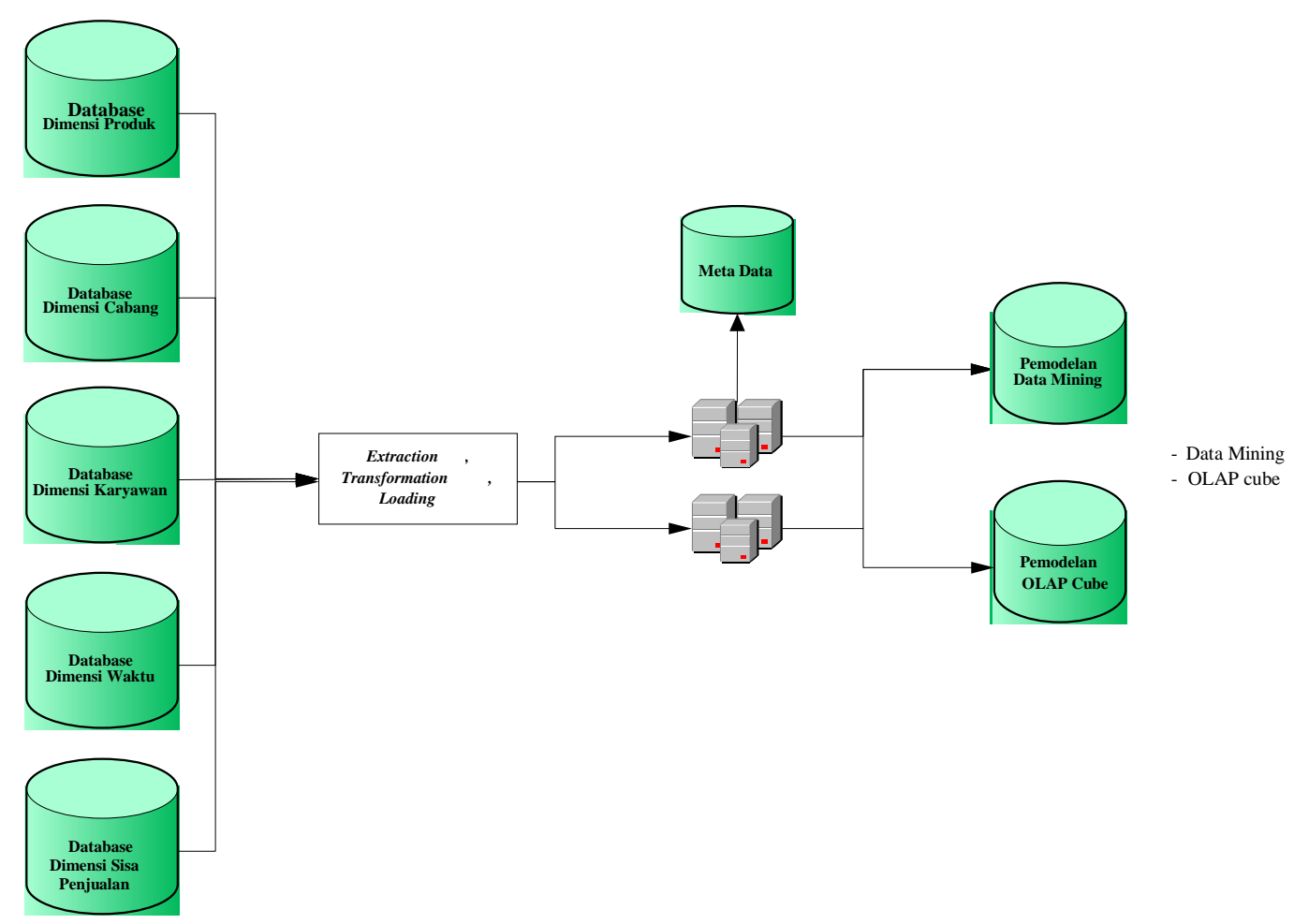

Gambar 4. Model arsitektur sistem intelijensia bisnis

Tabel 2. Database Penelitian

\begin{tabular}{ccccccc}
\hline Tahun & Bulan & Kode Cabang & Kode Produk & Nama Produk & $\begin{array}{c}\text { Jumlah } \\
\text { Produksi }\end{array}$ & $\begin{array}{c}\text { Jumlah } \\
\text { Penjualan }\end{array}$ \\
\hline 2016 & 6 & Cabang-001 & PROD-0000001 & Cokelat & 1201 & 1198 \\
2016 & 6 & Cabang-001 & PROD-0000002 & Kelapa & 733 & 730 \\
2016 & 6 & Cabang-001 & PROD-0000003 & Sarikaya & 744 & 771 \\
2016 & 6 & Cabang-001 & PROD-0000004 & Mocha & 660 & 659 \\
2016 & 6 & Cabang-001 & PROD-0000005 & Donut & 849 & 845 \\
2016 & 6 & Cabang-001 & PROD-0000006 & Sate & 759 & 754 \\
2016 & 6 & Cabang-001 & PROD-0000007 & Piscok & 822 & 819 \\
2016 & 6 & Cabang-001 & PROD-0000008 & Keju & 779 & 777 \\
2016 & 6 & Cabang-001 & PROD-0000009 & Piscokkeju & 997 & 993 \\
2016 & 6 & Cabang-001 & PROD-0000010 & Kejucoklat & 960 & 959 \\
2016 & 6 & Cabang-001 & PROD-0000011 & Daging & 634 & 632 \\
2016 & 6 & Cabang-001 & PROD-0000012 & Sosis & 555 & 552 \\
2016 & 6 & Cabang-001 & PROD-0000013 & Sosis Abon & 588 & 585 \\
2016 & 6 & Cabang-001 & PROD-0000014 & Susu & 869 & 866 \\
2016 & 6 & Cabang-001 & PROD-0000015 & Tawar & 5026 & 5018 \\
2016 & 6 & Cabang-001 & PROD-0000016 & Kupas & 1343 & 1338 \\
2016 & 6 & Cabang-001 & PROD-0000017 & Set Kecil & 436 & 430 \\
2016 & 6 & Cabang-001 & PROD-0000018 & 5 Rasa & 375 & 370 \\
2016 & 6 & Cabang-001 & PROD-0000019 & Kpk & 390 & 386 \\
2016 & 6 & Cabang-001 & PROD-0000020 & Set Kotak & 429 & 425 \\
2016 & 6 & Cabang-001 & PROD-0000021 & Strawberry & 360 & 355 \\
2016 & 6 & Cabang-001 & PROD-0000022 & Agar & 188 & 182 \\
\hline
\end{tabular}

Pada penelitian ini terdiri dari beberapa database yang akan dilakukan proses ETL dalam pembuatan OLTP. Tabel 3 dan Gambar 4 meyajikan database penelitian di R Bakery.

\section{Proses ETL (Extract, Transform, Load)}

ETL adalah proses untuk mengekstrak data dari database OLTP yang kemudian menampilkan data yang akan di transform yang selanjutnya di load menjadi sebuah database OLAP. (Mulyana, 2014).

\section{Dimensi Produk}

Pada database dimensi produk merupakan penggabungan dari beberapa sistem OLTP yaitu ms_penjualan dan ms_produk. Penggabungan sistem OLTP ini kemudian menjadi sebuah sistem OLAP 
yaitu dim_produk. Model sistem OLTP dalam pembentukan dimensi produk disajikan pada Gambar 6.

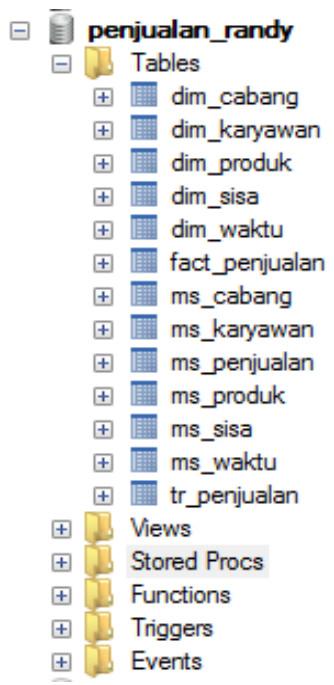

Gambar 5. Database R Bakery

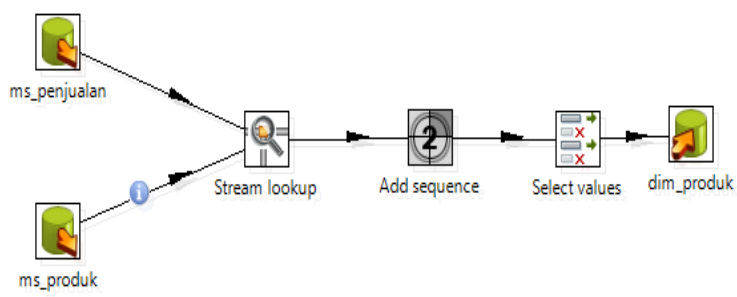

Gambar 6. Model dimensi produk

\section{Dimensi Cabang}

Database dimensi cabang bersumber dari ms_cabang yang kemudian dihubungkan dengan stream lookup. Kemudian dihubungkan dengan add sequence yang akan digunakan untuk menghasilkan nomor urut dengan nama sk_cabang. Kemudian dihubungkan dengan select values. Langkah terakhir adalah dengan menghubungkan tabel ouput dim_cabang. Tabel output ini kemudian akan di execute kedalam software SQLYog sebagai database yang baru yaitu dim_cabang. Model sistem OLTP dalam pembentukan dimensi cabang disajikan pada Gambar 7

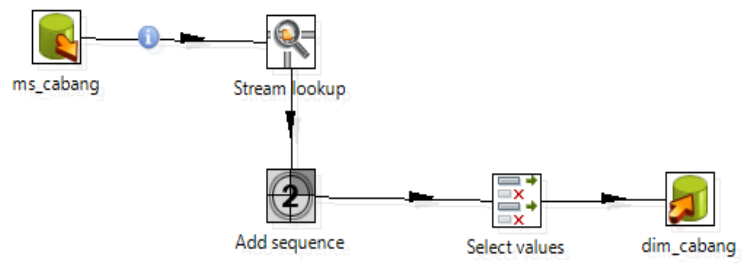

Gambar 7. Spoon dimensi cabang

\section{Dimensi Karyawan}

Pada database dimensi produk merupakan penggabungan dari beberapa sistem OLTP yaitu ms_cabang dan ms_karyawan. Penggabungan sistem OLTP ini kemudian menjadi sebuah sistem OLAP yaitu dim_produk. Model sistem OLTP dalam pembentukan dimensi karyawan disajikan pada Gambar 8.

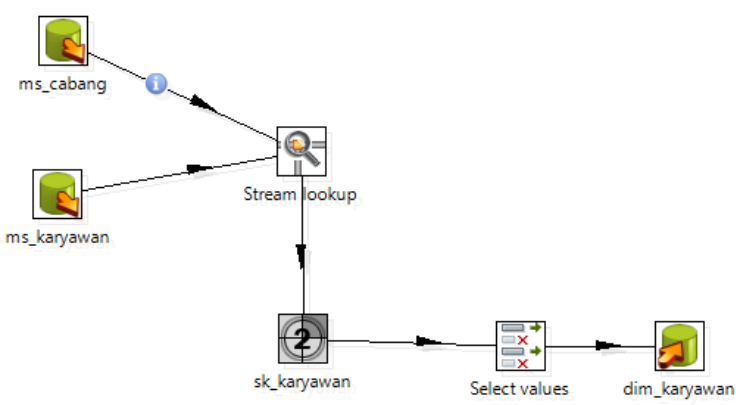

Gambar 8. Spoon dimensi karyawan

\section{Dimensi Waktu}

Database dimensi cabang bersumber dari ms_waktu yang kemudian dihubungkan dengan stream lookup. Kemudian dihubungkan dengan add sequence yang akan digunakan untuk menghasilkan nomor urut dengan nama sk_date. Kemudian dihubungkan dengan select values. Langkah terakhir adalah dengan menghubungkan tabel ouput dim_waktu. Tabel output ini kemudian akan di execute kedalam software SQLYog sebagai database yang baru yaitu dim_waktu. Sistem OLTP dalam pembentukan dimensi waktu disajikan pada Gambar 9.

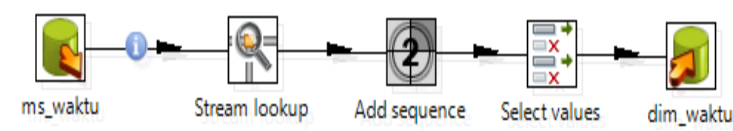

Gambar 9. Spoon dimensi waktu

Database dimensi cabang bersumber dari ms_waktu yang kemudian dihubungkan dengan stream lookup. Kemudian dihubungkan dengan add sequence yang akan digunakan untuk menghasilkan nomor urut dengan nama sk_date. Kemudian dihubungkan dengan select values. Langkah terakhir adalah dengan menghubungkan tabel ouput dim_waktu. Tabel output ini kemudian akan di execute kedalam software SQLYog sebagai database yang baru yaitu dim_waktu. Sistem OLTP dalam pembentukan dimensi waktu disajikan pada Gambar 9.

\section{Dimensi Sisa}

Database dimensi cabang bersumber dari ms_cabang yang kemudian dihubungkan dengan stream lookup. Kemudian dihubungkan dengan add sequence yang akan digunakan untuk menghasilkan nomor urut dengan nama sk_cabang. Kemudian dihubungkan dengan select values. Langkah terakhir adalah dengan menghubungkan tabel ouput dim_cabang. Tabel output ini kemudian akan di 
execute kedalam software SQLYog sebagai database yang baru yaitu dim_cabang. Sistem OLTP dalam pembentukan dimensi cabang disajikan pada Gambar 10.

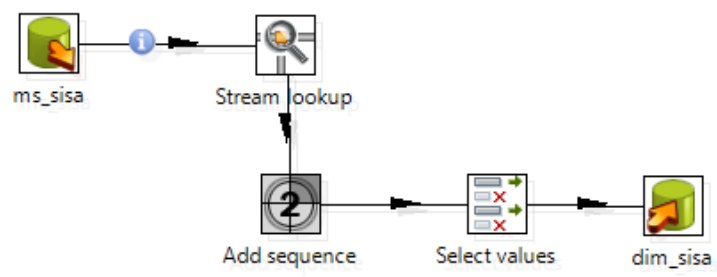

Gambar 10. Spoon dimensi sisa penjualan

\section{Fact Penjualan}

Pada sistem intelijensia bisnis, database yang diperlukan antara lain database dimensi produk, dimensi karyawan, dimensi cabang, dimensi waktu, dimensi sisa penjualan dan fact penjualan. Database fact penjualan merupakan penggabungan antara dimensi produk, dimensi karyawan, dimensi cabang, dimensi waktu, dan dimensi waktu. Pada gambar diatas menjelaskan visualisasi terbentuknya database fact penjualan yang mana database tersebut berisi mengenai informasi data produksi, data penjualan dan data sisa penjualan.

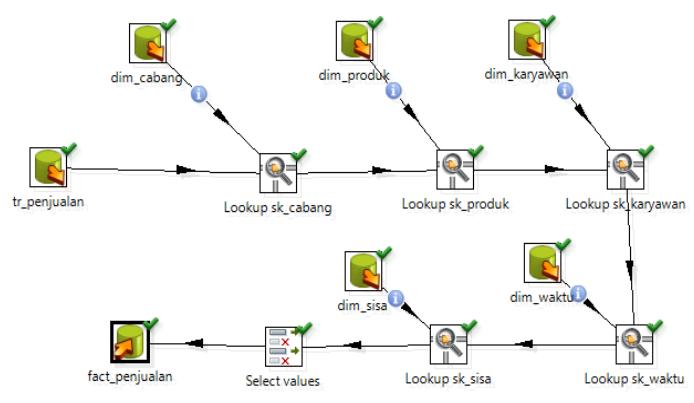

Gambar 11. Spoon fact penjualan

\section{Pengolahan OLAP Cube}

Pada tahap pengolahan cube, tahap perama yang dilakukan adalah dengan membuat schema. Schema tersebut berisi database apa saja yang digunakan sehingga akan menampilkan hasil yang dapat menampilkan bentuk kubus yang dapat dilihat pada Gambar 12.

Dalam proses pembuatan OLAP Cube terdiri dari proses pembuatan struktur database yaitu Struktur OLTP dan struktur OLAP. Pembuatan OLTP ini merupakan system yang memproses transaksi di R Bakery setiap harinya, sedangkan OLAP adalah suatu proses yang digunakan untuk melakukan analisis data penjualan R Bakery. OLAP biasanya digunakan untuk pengambilan keputusan. Pada kasus ini OLAP dapat memberikan keputusan berupa produk mana yang paling laku terjual dan di cabang mana paling banyak terjualnya roti. Struktur OLTP dan OLAP database penjualan R Bakery disajikan pada Gambar 13 dan 14.

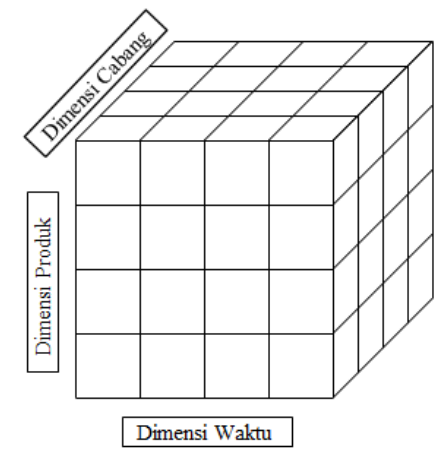

Gambar 12. OLAP Cube

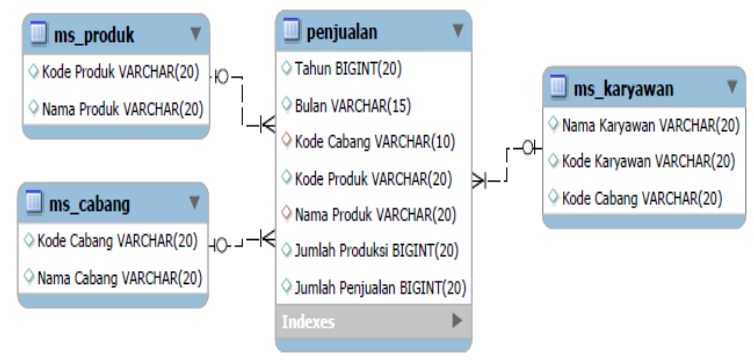

Gambar 13. Struktur OLTP Database penjualan R Bakery

Langkah selanjutnya adalah pembuatan schema. Adapun database yang digunakan dalam schema ini adalah dimensi produk, dimensi waktu, dan dimensi cabang. Gambar 5 merupakan gambaran schema menggunakan software schema workbench.

\begin{tabular}{|c|c|c|c|c|c|c|}
\hline \multicolumn{7}{|c|}{$\square$ Schema - randy (Schema9try.xml) } \\
\hline 名 & $\lambda_{t}$ & Ket & 秥卒 & NS & UDF & $\mathrm{CM}$ \\
\hline \multicolumn{7}{|c|}{$\Theta \times$ schema } \\
\hline \multicolumn{7}{|c|}{ Q $\varnothing$ xpenjualan } \\
\hline \multicolumn{7}{|c|}{ - 㶌 Table: fact_penjualan } \\
\hline \multicolumn{7}{|c|}{ - fee dim_produk } \\
\hline \multicolumn{7}{|c|}{ \&er dim_waktu } \\
\hline \multicolumn{7}{|c|}{ Afor dim_cabang } \\
\hline \multicolumn{7}{|c|}{ Jumlan Penjualan } \\
\hline \multicolumn{7}{|c|}{ i_ A xdim_produk } \\
\hline \multicolumn{7}{|c|}{ P- 花施 XProduk } \\
\hline \multicolumn{7}{|c|}{ hingh Kode Produk } \\
\hline \multicolumn{7}{|c|}{ hing Nama Produk } \\
\hline \multicolumn{7}{|c|}{ L 壣 Table: dim_produk } \\
\hline \multicolumn{7}{|c|}{ i- 丸 xdim_waktu } \\
\hline \multicolumn{7}{|c|}{ P- 雇局 XWaktu } \\
\hline \multicolumn{7}{|c|}{ then Tahun } \\
\hline \multirow{2}{*}{\multicolumn{7}{|c|}{ - minth Bulan }} \\
\hline \multicolumn{6}{|c|}{ L 淎 Table: dim_waktu } & \\
\hline \multicolumn{7}{|c|}{ P \& xdim_cabang } \\
\hline \multicolumn{7}{|c|}{9 㚙后 XCabang } \\
\hline \multicolumn{7}{|c|}{ hong Kode Cabang } \\
\hline \multicolumn{7}{|c|}{ - 非 Table: dim_cabang } \\
\hline Dat & abase & -penj & alan__ & andy ( & MySQ & \\
\hline
\end{tabular}

Gambar 14. Penggabungan Dimensi OLAP

Dari schema tersebut kemudian dilanjutkan dengan mengaplikasikan ke software Pentaho Analysis. Pentaho adalah software yang digunakan untuk pembuatan data warehouse dan business 
intelligence. (Mulyana, 2014). Gambar 16 menyajikan hasil dan tampilan dari analisa Pentaho berdasarkan schema workbench yang telah dibuat.

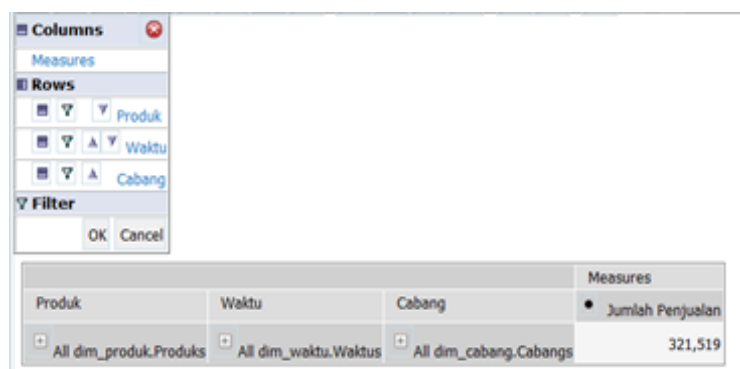

Gambar 15. Analisa Pentaho

Pada Gambar 16 dapat disimpulkan bahwa jumlah penjualan yang dihasilkan selama 8 bulan yaitu 321.519 buah.

\section{Analisis Pemasaran Menggunakan Data Mining}

Data mining adalah proses penggalian data yang bertujuan untuk memperoleh informasi dari data yang tergabung dari berbagai sumber yang akan mempermudah dalam pengambilan keputusan. Metode data mining yang digunakan adalah metode clustering k-means. Hal pertama yang dilakukan dalam perhitungan clustering k-means adalah menentukan jumlah cluster. Dalam penelitian ini cluster-nya terdiri dari 2 cluster. Kemudian untuk menentukan pusat centroid yaitu menemukan titik utama pada data yang diperoleh yaitu dengan dilakukan secara acak atau random. Kemudian untuk menentukan jarak centroid yaitu menggunakan perhitungan jarak data dengan centroid.

Iterasi ke -1

1. Penentuan pusat awal cluster

Untuk penentuan awal diasumsikan :

Diambil data ke-14 sebagai pusat cluster ke-1 : $(18,23)$

Diambil data ke-20 sebagai pusat cluster ke-2 : $(30,40)$

2. Perhitungan jarak pusat cluster

Untuk mengukur jarak antara data dengan titik utama cluster yaitu menggunakan rumus Euclidean distance (Santosa, 2007).

$$
\mathbf{d}(\mathbf{x}, \mathbf{y})=|\mathbf{x}-\mathbf{y}|=\sqrt{\sum_{\mathrm{i}=1}^{\mathrm{n}}\left(\mathrm{x}_{\mathrm{i}}-y_{i}\right)^{2}}
$$

Kesimpulan akhir dari perhitungan clustering dapat dilihat pada Tabel 4. Berdasarkan Tabel 4, terdiri dari 19 produk yang cluster 1 dan 4 produk yang cluster 2. Dapat disimpulkan bahwa terdiri dari $83 \%$ cluster 1 dan $17 \%$ cluster 2.

Cluster 1 merupakan kategori sisa roti yang rendah dan cluster 2 merupakan kategori sisa roti yang tinggi. Dapat disimpulkan dari tabel 3, bahwa roti coklat, kelapa, sarikaya, mocha, donut, sate, piscok, keju, pisang coklat keju, keju coklat, daging, sosis abon, susu, tawar, kupas, 5 rasa, strawberry, agar, dan blueberry merupakan cluster 1 yang merupakan kategori sisa penjualan roti yang rendah, sedangkan roti sosis, set kecil, KPK, dan set kotak merupakan cluster 2 yang merupakan kategori sisa penjualan roti yang tinggi.

Tabel 3. Hasil clustering akhir

\begin{tabular}{|c|c|c|c|c|}
\hline Kode Produk & Nama Produk & $\begin{array}{c}\text { Sisa Penjualan } \\
\text { Binong }\end{array}$ & $\begin{array}{c}\text { Sisa Penjualan } \\
\text { Perum }\end{array}$ & Cluster \\
\hline PROD-0000001 & Cokelat & 19 & 12 & 1 \\
\hline PROD-0000002 & Kelapa & 25 & 30 & 1 \\
\hline PROD-0000003 & Sarikaya & 23 & 26 & 1 \\
\hline PROD-0000004 & Mocha & 30 & 23 & 1 \\
\hline PROD-0000005 & Donut & 24 & 18 & 1 \\
\hline PROD-0000006 & Sate & 19 & 22 & 1 \\
\hline PROD-0000007 & Piscok & 21 & 17 & 1 \\
\hline PROD-0000008 & Keju & 24 & 20 & 1 \\
\hline PROD-0000009 & Piscokkeju & 36 & 19 & 1 \\
\hline PROD-0000010 & Kejucoklat & 20 & 22 & 1 \\
\hline PROD-0000011 & Daging & 21 & 31 & 1 \\
\hline PROD-0000012 & Sosis & 29 & 34 & 2 \\
\hline PROD-0000013 & Sosis Abon & 20 & 24 & 1 \\
\hline PROD-0000014 & Susu & 18 & 23 & 1 \\
\hline PROD-0000015 & Tawar & 34 & 19 & 1 \\
\hline PROD-0000016 & Kupas & 25 & 19 & 1 \\
\hline PROD-0000017 & Set Kecil & 33 & 36 & 2 \\
\hline PROD-0000018 & 5 Rasa & 23 & 32 & 1 \\
\hline PROD-0000019 & Kpk & 32 & 32 & 2 \\
\hline PROD-0000020 & Set Kotak & 30 & 40 & 2 \\
\hline PROD-0000021 & Strawberry & 24 & 34 & 1 \\
\hline PROD-0000022 & Agar & 22 & 32 & 1 \\
\hline PROD-0000023 & Blueberry & 22 & 22 & 1 \\
\hline
\end{tabular}




\section{Usulan Perbaikan Data Mining R Bakery}

Berdasarkan hasil data mining pada penelitian ini, hasil yang didapatkan dari clustering adalah sisa roti pada penjualan di Binong dan di Perum. Usulan yang tepat untuk mengurangi jumlah sisa roti adalah dengan meningkatkan pemasaran dengan menyajikan roti dengan menarik dan membuat lebih banyak variansi roti mengikuti perkembangan waktu, meningkatkan kualitas roti agar dapat bersaing dengan pesaing, membuat produk baru yang lebih menarik dibanding kompetitor agar masyarakat tidak mudah bosan dan memproduksi roti dengan daya simpan yang lebih lama terutama untuk roti tawar dan kupas.

\section{Pemodelan Customer Relationship Management (CRM)}

Metode yang digunakan untuk membangun customer relationship management untuk R Bakery adalah metode analisis pemasaran RFM (Recency, Frequency, Monetary) dan Customer Lifetime Value (CLV) yang digunakan untuk menentukan siklus hidup konsumen yang hasilnya dapat menentukan pedagang potensial oleh R Bakery. Berikut adalah rumus matematika untuk pemodelan CRM dengan RFM dan CLV (Rina et al., 2012).

\section{Nilai $C L V_{k}=\left(N_{k} x R_{k}\right)+\left(N_{k} x W F k\right)+\left(N M_{k}\right.$ $\mathbf{x} \mathbf{W M}_{\mathbf{k}}$ )}

$\mathrm{CLV}_{\mathrm{k}}=$ Customer Lifetime Value $=$ Nilai Siklus Hidup Konsumen ke $\mathrm{k}$

$\mathrm{NR}_{\mathrm{k}}=$ Normalisasi Recency

$\mathrm{WR}_{\mathrm{k}}=$ Bobot Recency

$\mathrm{NF}_{\mathrm{k}}=$ Normalisasi Frequency transaksi penjualan

$\mathrm{WF}_{\mathrm{k}}=$ Bobot Frequency

$\mathrm{NM}_{\mathrm{k}}=$ Normalisasi hasil penjualan

$\mathrm{WM}_{\mathrm{k}}=$ Bobot Monetary

$\mathrm{k}=$ pedagang roti

Tabel 4. Tabel bobot CLV

\begin{tabular}{|c|c|}
\hline $\mathrm{WR}_{\mathrm{k}}$ & 0,3 \\
\hline $\mathrm{WF}_{\mathrm{k}}$ & 0,35 \\
\hline $\mathrm{WM}_{\mathrm{k}}$ & 0,35 \\
\hline
\end{tabular}

Keterangan kategori RFM :

$\mathrm{NR}_{\mathrm{k}}=$ untuk (high, medium, low) nilai $\mathrm{NR}_{\mathrm{k}}$ adalah $(1,2,3)$

$\mathrm{NF}_{\mathrm{k}}=$ untuk (high, medium, low) nilai $\mathrm{NF}_{\mathrm{k}}$ adalah $(3,2,1)$

$\mathrm{NM}_{\mathrm{k}}=$ untuk (high, medium, low) nilai $\mathrm{NF}_{\mathrm{k}}$ adalah $(3,2,1)$

Tabel 5. Kategori RFM

\begin{tabular}{lccc}
\hline & Low & Medium & High \\
\hline Recency & 1 & $2-3$ & $4-5$ \\
Frequency & $15-20$ & $21-25$ & $26-30$ \\
Monetory & $9.000 .000-10.00000$ & $10.100 .000-11.500 .000$ & $11.600 .000-12.700 .000$ \\
\hline
\end{tabular}

Tabel 6. Hasil RFM pada bulan September 2016

\begin{tabular}{|c|c|c|c|c|c|c|}
\hline $\begin{array}{c}\text { Nama } \\
\text { Pedagang }\end{array}$ & Frekuensi & Monetory & Recency & Kelas Frequency & $\begin{array}{c}\text { Kelas } \\
\text { Monetory }\end{array}$ & $\begin{array}{c}\text { Kelas } \\
\text { Recency }\end{array}$ \\
\hline $\mathrm{JJ}$ & 30 hari/bln & 10.258 .000 & 1 & High & Medium & Low \\
\hline MR & 30 hari/bln & 10.237 .000 & 1 & High & Medium & Low \\
\hline $\mathrm{AQ}$ & 24 hari/bln & 11.447 .500 & 2 & Medium & Medium & Medium \\
\hline $\mathrm{BD}$ & 25 hari/bln & 12.384 .500 & 2 & Medium & High & Medium \\
\hline LM & 24 hari/bln & 12.025 .500 & 2 & Medium & High & Medium \\
\hline DF & 23 hari/bln & 12.497 .500 & 3 & Medium & High & Medium \\
\hline YY & 26 hari/bln & 11.968 .000 & 3 & High & High & Medium \\
\hline CK & 17 hari/bln & 10.105 .000 & 5 & Low & Low & High \\
\hline MK & 25 hari/bln & 10.546 .500 & 2 & Medium & Medium & Medium \\
\hline IR & 24 hari/bln & 11.264 .000 & 2 & Medium & Medium & Medium \\
\hline ST & 27 hari/bln & 12.041 .500 & 3 & High & High & Medium \\
\hline SM & 28 hari/bln & 12.399 .000 & 3 & High & High & Medium \\
\hline AW & 30 hari/bln & 10.168 .000 & 1 & High & Low & Low \\
\hline UD & 30 hari/bln & 11.565 .000 & 1 & High & Medium & Low \\
\hline FA & 30 hari/bln & 9.823 .000 & 1 & High & Low & Low \\
\hline SW & 18 hari/bln & 10.542 .000 & 5 & Low & Medium & High \\
\hline $\mathrm{BL}$ & 21 hari/bln & 11.185 .000 & 4 & Medium & Medium & High \\
\hline AT & 23 hari/bln & 10.749 .000 & 3 & Medium & Medium & Medium \\
\hline $\mathrm{PN}$ & 20 hari/bln & 10.177 .500 & 4 & Low & Low & High \\
\hline MY & 19 hari/bln & 12.097 .000 & 4 & Low & High & High \\
\hline $\mathrm{AJ}$ & 30 hari/bln & 12.625 .500 & 1 & High & High & Low \\
\hline $\mathrm{AD}$ & 29 hari/bln & 11.250 .000 & 2 & High & Medium & Medium \\
\hline DL & 22 hari/bln & 11.610 .000 & 4 & Medium & High & High \\
\hline KW & 30 hari/bln & 9.677 .500 & 1 & High & Low & Low \\
\hline
\end{tabular}


Dari hasil RFM tersebut pada Tabel 7 diaggregasi sebagai logical cube yang berbasis OLAP. Untuk meminimasi Recency, maksimasi Frequency, dan maksimasi monetary dikumpulkan dengan CLV (Customer Lifetime Value) terbaik dari bulan September 2016. Logical cube RFM disajikan pada Gambar 17 dan ringkasan dari hasil CLV disajikan pada Tabel 8.

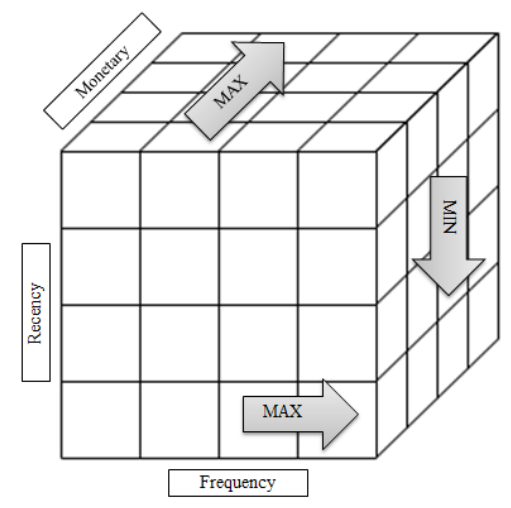

Gambar 16. Cube RFM

\section{Usulan Perbaikan CLV (Customer Lifetime Value)}

CLV menghasilkan output berupa ranking dari pedagang di R Bakery. Usulan yang diberikan adalah dengan memberikan penghargaan kepada pedagang ranking 1 hingga 3 dan memberikan semangat dan motivasi kepada pedagang yang ranking dibawah 3. Usulan ini diberikan agar pada pedagang lebih semangat dalam memasarkan produk roti R Bakery.

\section{Usulan Perbaikan Strategi Pemasaran Untuk R Bakery}

Untuk meningkatkan pemasaran R Bakery agar lebih, diusulkan strategi pemasaran yang dianalisis menggunakan metode SWOT (Strength, Weakness, Opportunities, Threath). Analisis SWOT dilakukan dengan 2 tahap yaitu analisis internal yang dilakukan dengan membuat matriks IFAS (Internal Factors Analysis Summary) dan matriks EFAS (External Factors Analysis Summary). Matrik SWOT dapat menghasilkan 4 strategi yang dapat dilakukan R Bakery. Adapun usulan Matrik SWOT R Bakery disajikan pada Tabel 9 .

Berdasarkan tabel 9, dalam analisis SWOT menunjukkan strategi SO menghasilkan usulan untuk memaksimalkan kekuatan dan peluang yang ada, strategi yang dapat dilakukan R Bakery adalah dengan menyajikan roti dengan menarik dan membuat lebih banyak variansi roti mengikuti perkembangan waktu dan menambah lokasi pemasaran agar lebih banyak pelanggan mengenal $\mathrm{R}$ Bakery.

Strategi WO menghasilkan usulan untuk memaksimalkan peluang yang ada serta meminimalkan kelemahan, strategi yang dapat dilakukan $\mathrm{R}$ Bakery adalah dengan memproduksi roti dengan daya simpan yang lebih lama dan mengatur jadwal pemasaran yang benar agar pelanggan mudah menemukan pedagang.

Tabel 7. Tabel ranking CLV bulan September 2016

\begin{tabular}{ccccccccc}
\hline $\begin{array}{c}\text { Nama } \\
\text { Pedagang }\end{array}$ & Frekuensi & Monetary & Recency & $\begin{array}{c}\text { Kelas } \\
\text { Frekuensi }\end{array}$ & $\begin{array}{c}\text { Kelas } \\
\text { Monetory }\end{array}$ & $\begin{array}{c}\text { Kelas } \\
\text { Recency }\end{array}$ & CLV & Ranking \\
\hline MY & 19 hari/bln & 12.097 .000 & 4 & Low & High & High & 3 & 1 \\
JJ & 30 hari/bln & 10.258 .000 & 1 & High & Medium & Low & 2,65 & 2 \\
MR & 30 hari/bln & 10.237 .000 & 1 & High & Medium & Low & 2,65 & 2 \\
UD & 30 hari/bln & 11.565 .000 & 1 & High & Medium & Low & 2,65 & 2 \\
SW & 18 hari/bln & 10.542 .500 & 5 & Low & Medium & High & 2,65 & 2 \\
BD & 25 hari/bln & 12.384 .500 & 2 & Medium & High & Medium & 2,35 & 3 \\
LM & 24 hari/bln & 12.025 .500 & 2 & Medium & High & Medium & 2,35 & 3 \\
DF & 23 hari/bln & 12.497 .500 & 3 & Medium & High & Medium & 2,35 & 3 \\
BL & 21 hari/bln & 11.185 .000 & 4 & Medium & Medium & Medium & 2,35 & 3 \\
CK & 17 hari/bln & 10.105 .000 & 5 & Low & Low & High & 2,3 & 4 \\
PN & 20 hari/bln & 10.177 .500 & 4 & Low & Low & High & 2,3 & 4 \\
YY & 26 hari/bln & 11.968 .000 & 3 & High & High & Medium & 2,05 & 5 \\
ST & 27 hari/bln & 12.041 .500 & 3 & High & Low & Low & 2,05 & 5 \\
SM & 28 hari/bln & 12.399 .000 & 3 & High & Medium & Low & 2,05 & 5 \\
AQ & 24 hari/bln & 11.447 .500 & 2 & Medium & Medium & Medium & 2 & 6 \\
MK & 25 hari/bln & 10.546 .500 & 2 & Medium & Medium & Medium & 2 & 6 \\
IR & 24 hari/bln & 11.264 .000 & 2 & Medium & Medium & Medium & 2 & 6 \\
AT & 23 hari/bln & 10.749 .000 & 3 & Medium & Medium & Medium & 2 & 6 \\
AD & 29 hari/bln & 11.250 .000 & 2 & High & Medium & Medium & 1,7 & 7 \\
AJ & 30 hari/bln & 12.625 .500 & 1 & High & High & Low & 1,7 & 7 \\
DL & 22 hari/bln & 11.610 .000 & 4 & Medium & High & High & 1,3 & 8 \\
AW & 30 hari/bln & 10.168 .000 & 2 & High & Low & Low & 1 & 9 \\
FA & 30 hari/bln & 9.823 .000 & 1 & High & Low & Low & 1 & 9 \\
KW & 30 hari/bln & 9.677 .500 & 1 & High & Low & Low & 1 & 9 \\
\hline
\end{tabular}


Tabel 8. Matrik SWOTR Bakery

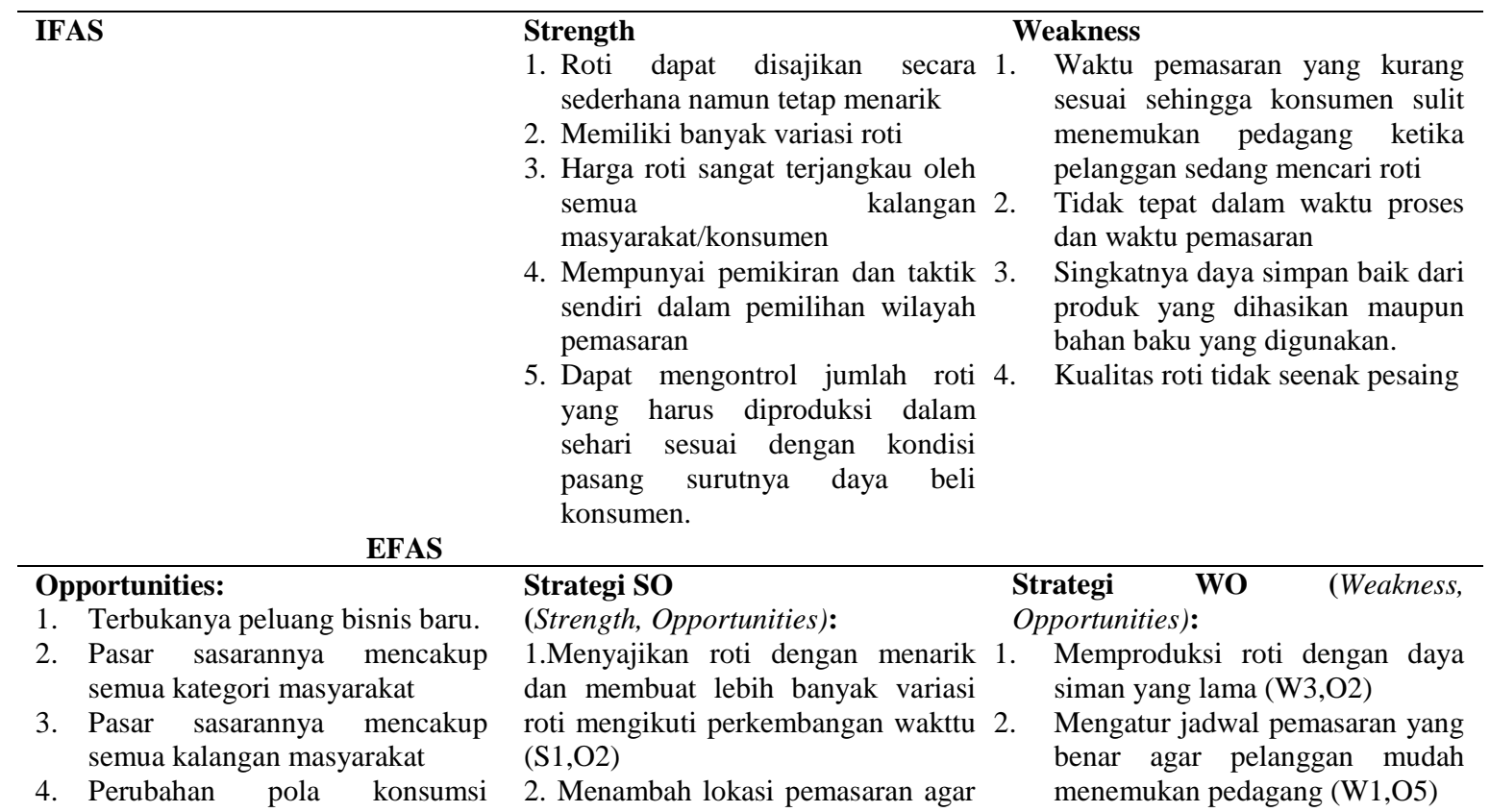
masyarakat Indonesia di kota lebih banyak calon pelanggan besar yang mulai mengkonsumsi mengenal R Bakery (S4,O5) roti sebagai pengganti nasi.

5. Lokasi pemasaran berada dalam jangkauan wilayah pabrik.

Threath :

1. Faktor kenaikan harga sembako yang dapat mengurangi pendapatan per harinya

2. Banyak competitor yang memiliki gerai yang menyedikan produk yang masih hangat

3. Mudah jenuhnya konsumen terhadap produk

4. Tempat pemasaran yang kurang banyak

5. Jumlah kompetitor yang sangat banyak

Strategi ST(Strenght, Threath):

1. Membuat produk baru yang lebih menarik agar konsumen tidak mudah bosan.(S1,T3)

2. Meyediakan roti yang hangat menggunakan gerobak yang memiliki penghangat roti $(\mathrm{S} 1, \mathrm{~T} 2)$

\section{Strategi OT (Opportunities,}

Threath):

1. Memproduksi roti dengan daya simpan yang lama terutama untuk roti tawar dank upas (W3,T2)

2. Memperbaiki dan meningkatkan kualitas roti agar dapat bersaing (W4,T5)
Strategi ST menghasilkan usulan untuk memaksimalkan kekuatan yang ada serta meminimalkan ancaman, strategi yang dapat dilakukan $\mathrm{R}$ Bakery adalah dengan membuat produk baru yang lebih menarik dibanding kompetitor agar masyarakat tidak mudah bosan dan menyediakan roti yang hangat yang dijual menggunakan gerobak yang memiliki penghangat roti agar roti tetap hangat.

Strategi WT menghasilkan usulan untuk meminimalkan kelemahan dan ancaman, strategi yang dapat dilakukan $\mathrm{R}$ Bakery adalah dengan memproduksi roti dengan daya simpan yang lebih lama terutama untuk roti tawar dan kupas. Strategi lainnya berupa memperbaiki dan meningkatkan kualitas roti agar dapat bersaing dengan kompetitor.

\section{KESIMPULAN DAN SARAN}

\section{Kesimpulan}

Model sistem intelijensia bisnis pada pabrik roti dengan studi kasus $\mathrm{R}$ Bakery menghasilkan output berupa model cube dan data mining yang menampilkan hasil visual yang akan membantu dalam pengambilan keputusan untuk meningkatkan pemasaran. Hasil data mining clustering k-means adalah terdiri dari $83 \%$ cluster 1 dan $17 \%$ cluster 2 . Cluster 1 merupakan kategori sisa roti yang rendah dan cluster 2 merupakan kategori sisa roti yang tinggi. Hasil yang diperoleh dari On Line Analitical Process Cube adalah berupa data warehouse penjualan R Bakery. Dari perhitungan CLV untuk pemodelan CRM diketahui bahwa urutan pedagang dengan ranking CLV tertinggi adalah pedagang MY yaitu pedagang yang memiliki kelas frequency low namun kelas monetary dan kelas recency high. Usulan untuk memperbaiki strategi pemasaran menggunakan SWOT Analysis adalah menyajikan roti dengan menarik dan membuat lebih banyak variansi roti mengikuti perkembangan waktu, membuat tempat pemasaran yang lebih banyak, membuat produk baru yang lebih menarik dibanding kompetitor, dan memproduksi roti dengan daya 
simpan yang lebih lama terutama untuk roti tawar dan kupas.

\section{SARAN}

Penelitian lebih lanjut mengenai sistem intelijensia bisnis dengan kombinasi beberapa metode data mining dapat terus dikembangkan.

\section{DAFTAR PUSTAKA}

Agusta Y. 2007. K-means penerapan, permasalahan dan metode terkait. Jurnal Sistem dan Informatika. 3 : 47-60.

Benoit FD dan Van DPD. 2009. Benefits of quantile regression for the analysis of customer lifetime value in a contractual setting: An application in financial services. Expert Systems with Applications. 36 (7) :1047510484.

Cartaya dan Juan CC. 2008. La inteligencia empresarial y el Sistema de Gestión de Calidad ISO 9001:2000. Ciencias de la Información. 39 (1):31-44.

Fatta A dan Hanif. 2007. Analisis dan Perancangan Sistem Informasi. Yogyakarta : ANDI.

Fitriana R, Eriyatno, dan Djatna T. 2011. Progress in business intelligence system research : a literature review. International Journal Basic \& Applied Sciences. 11 (03):96-105.

Fitriana R, Eriyatno, Djatna T, Kusmuljono BS. 2012. Peran sistem intelijensia bisnis dalam manajemen pengelolaan pelanggan dan mutu untuk agroindustri susu skala usaha menengah. Jurnal Teknologi Industri Pertanian. 22 (3) : $131-139$.

Fitriana R. 2013. Rancang bangun sistem intelijensia bisnis untuk agroindustri susu skala menengah di Indonesia. [Disertasi]. Bogor : Institut Pertanian Bogor.

Fitriana R, Saragih J, dan Firmansyah MA. 2016. Business Intelligence System Model Proposals to Improve the Quality of Service at PT GIA. Proceeding of $9^{\text {th }}$ International Seminar on Industrial Engineering and Management. Padang, Indonesia: $20-22$ September 2017.

Fitriana R, Saragih J, dan Lutfiana N. 2017. Model business intelligence system design of quality products by using data mining in $R$ Bakery Company. Proceeding of $10^{\text {th }}$. International Seminar on Industrial Engineering and Management. Belitung, Indonesia: 7-9 September 2017.

Fuentes T dan Louis. 2010. Incorporation of business intelligence elements in the admission and registration process of a Chilean University. Ingeniare - Revista Chilena de Ingeniería. 18(3): 383-394.

Ghazanfari M, Jafari M, dan Rouhani S. 2011. A tool to evaluate the business intelligence of enterprise systems. Journal Scientia Iranica, Transactions E: Industrial Engineering. 18 (6): 1579-1590. doi:10.1016/ j.scient. 2011.11.011.

Golfarelli M, Mandreoli F, PenzoW, Rizzi S, Turricchia E. 2012. OLAP query reformulation in peer-to-peer data warehousing. Information Systems. 37(5): 393-411.

Haenlien M, Kaplan AM, dan Beeser AJ. 2007. A model to determine customer lifetime value in a retail banking context. European Management Journal. 3 (5): 221-234.

Hayashi Y. 2010. Understanding consumer heterogeneity: A business intelligence application of neural networks. KnowledgeBased Systems. 23(8): 856-863.

Head SC, Nielson AR, dan Au MK. 2010. Using commercial off-the-shelf business intelligence software tools to support aircraft and automated test system maintenance environments. Autotestcon IEEE Conferences. Orlando, FL, USA: 13 -16 September 2010.

Hidalgo P, Manzur E, Olavarrieta S, Farías P. 2007. Customer retention and price matching: the afps case. Journal Business Research. 61 (6): 691-696.

Imelda. 2011. Business Intelligence. Jurnal Majalah Ilmiah UNIKOM. 11(1):111-122.

Jadav JJ dan Panchal M. 2012. Association rule mining method on OLAP Cube. International Journal Engineering Research and Applications. 2 (2):1147-1151.

Jie H. 2010. Research on mechanism and applicable framework of e-business intelligence. (ICEE). International Conference E-Business and EGovernment. Guangzhou, China: 7-9 May 2010. doi. 10.1109/ICEE.2010.57.

Kamel R. 2002. PUZZLE: A concept and prototype for linking business intelligence to business strategy. Journal Strategic Information Systems. 11(2): 133-152.

Kanth A, Mushtag A, dan Khan RA. 2015. Data Mining For Marketing. Norderstedt Germany: GRIN Verlag GmbH.

Kleesuwan S, Mithata S, Yupapin P, Piyatamrong B. 2010. Business intelligence in thailand's higher educational resources management. Procedia Social and Behavioral Sciences. 2: 84-87.

Ko IS dan Abdullaev SR. 2007. A Study on the aspects of successful business intelligence system development. International Conference on Computational Science. Beijing, China. 27-30 May 2007 Di dalamShi Y, van Albada GD, Dongarra J, Sloot PMA (ed), Computer Science - ICCS 2007. Lecturer Note in Book Science. Beijing China :Springer. 
Kotler P dan Keller. 2009. Manajemen Pemasaran. I (13). Jakarta: Erlangga.

Larose DT. 2006. Data Mining Methods and Models. New Jersey: John Wiley \& Sons, Inc., Hoboken.

Liu L. 2010. Supply Chain Integration through Business Intelligence; Management and Service Science (MASS). International Conference on Mathematical and Statistical Science. Cape Town South Africa. 27-29 Januari 2010. doi: 10.1109/ICMSS. 2010.5577534.

Li ST, Shue LY, dan Lee SF. 2008. Business intelligence approach to supporting strategymaking of ISP service management. Journal Expert Systems with Applications: An International Journal 35(3):739754.doi:10.1016/j.eswa.2007.07.049.

Maira P. 2009. Managing sustainability with the support of business intelligence: Integrating socio-environmental indicators and organisational context. Journal Strategic Information Systems. 18 (4): 178-191.

Marjanovic O. 2010. Business Value Creation through Business Processes Management and Operational Business Intelligence Integration. $43^{\text {rd }} \quad$ Hawaii International Conference on System Science (HICSS). Honolulu, HI, USA. 5-8 Januari 2010. doi : 10.1109/HICSS.2010.89.

Ming M, Zehui L, dan Jinyuan C. 2008. Phase-type distribution of customer relationship with Markovian response and marketing expenditure decision on the customer lifetime value. European Journal Operational Research. $187: 313-326$.

Ming KC dan Shih CW. 2010. The use of a hybrid fuzzy-Delphi-AHP approach to develop global business intelligence for information service firms. Expert Systems with Applications. 37(11): 7394-7407.

Mulyana JRP. 2014. Pentaho:Solusi Open Source untuk Membangun Data Warehouse. Yokyakarta: Penerbit Andi.
Phan DD danVogel DR. 2010. A model of customer relationship management and business intelligence systems for catalogue and online retailers. Information \& Management. 47(2): 559-566.

Pillai J. 2011. User centric approach to itemset utility mining in market basket analysis. International Journal Computer Science \& Engineering. 3 (1): 393-400.

Polyvyanyy A, Ouyang C, Barros A, van der Aalst WMP. 2017. Process querying: Enabling business intelligence through query-based process analytics. Decision Support Systems. 100: 41-56.

Qwaider QW. 2012. Apply on-line analytical processing (olap) with data mining for clinical decision sopport. International Journal Managing Information Technology. 4(1): 25-37. doi:10.5121/ ijmit.2012.4103. 25.

Santosa B. 2007. Data Mining Teknik Pemanfaatan Data untuk Keperluan Bisnis. Yogyakarta : Graha Ilmu.

Stefanovic N dan Stefanovic D. 2009. Supply Chain Business Intelligence: Technologies, Issues and Trends di dalam M. Bramer (Ed.): Artificial Intelligence an Intl Perspective. Lecture Notes in Computer Science.5640. Berlin Heidelberg: Springer. P217-245.

Vercellis C. 2009. Business intelligence : data mining and optimization for decision making. Chichester: John Wiley \& Sons.

Whitten BD. 2004. System Analysis and Design Methods. $6^{\text {th }}$ Ed. The Mc Graw-Hill Companies. 